\title{
Effects of tofacitinib on lymphocyte sub-populations, CMV and EBV viral load in patients with plaque psoriasis
}

Fernando Valenzuela ${ }^{1}$, Kim A Papp ${ }^{2}$, David Pariser ${ }^{3}$, Stephen K Tyring ${ }^{4}$, Robert Wolk ${ }^{5}$, Marjorie Buonanno ${ }^{5}$, Jeff Wang ${ }^{6,8}$, Huaming Tan ${ }^{5}$ and Hernan Valdez ${ }^{7,9^{*}}$

\begin{abstract}
Background: Plaque psoriasis is a debilitating skin condition that affects approximately $2 \%$ of the adult population and for which there is currently no cure. Tofacitinib is an oral Janus kinase inhibitor that is being investigated for psoriasis.

Methods: The design of this study has been reported previously (NCT00678210). Patients with moderate to severe chronic plaque psoriasis received tofacitinib (2 mg, $5 \mathrm{mg}$, or $15 \mathrm{mg}$ ) or placebo, twice daily, for 12 weeks.

Lymphocyte sub-populations, cytomegalovirus (CMV) and Epstein-Barr virus (EBV) DNA were measured at baseline and up to Week 12.

Results: Tofacitinib was associated with modest, dose-dependent percentage increases from baseline in median B cell count at Week 4 (24-68\%) and Week $12(18-43 \%)$ and percentage reductions from baseline in median natural killer cell count at Week 4 (11-40\%). The proportion of patients with detectable CMV and EBV DNA (defined as $>0$ copies $/ 500$ ng total DNA) increased post-baseline in tofacitinib-treated patients. However, multivariate analyses found no relationship between changes in CMV or EBV viral load and changes in lymphocyte sub-populations or tofacitinib treatment.

Conclusions: Twelve weeks of treatment with tofacitinib had no clinically significant effects on CMV or EBV viral load, suggesting that lymphocyte sub-populations critical to the response to chronic viral infections and viral reactivation were not significantly affected. Replication of these findings during long-term use of tofacitinib will allow confirmation of this observation.
\end{abstract}

Keywords: Cytomegalovirus, Epstein-Barr virus, Janus kinase inhibition, Lymphocyte, Plaque psoriasis, Tofacitinib, Viral reactivation

\section{Background}

Psoriasis is a debilitating and recurring immune-mediated inflammatory disease that affects $0.91-8.5 \%$ of the adult population according to geographic region [1]. Plaque psoriasis is by far the most prevalent form, accounting for approximately $80 \%$ of cases [2]. Tofacitinib is an oral Janus kinase (JAK) inhibitor that is being investigated for psoriasis. Oral tofacitinib has been evaluated in a Phase I study

\footnotetext{
* Correspondence: hernan.valdez@pfizer.com

${ }^{7}$ Pfizer Inc, New York, NY, USA

${ }^{9}$ Specialty Care Medicines Development Group, Pfizer Inc, 219 E 42nd Street, 7th Floor Room 50, NYO 219/07/01, New York, NY 10017, USA

Full list of author information is available at the end of the article
}

in patients with active psoriasis [3], and in Phase II and Phase III studies in patients with chronic plaque psoriasis [4-6] (see also NCT01276639 and NCT01309737). Tofacitinib binds to and inhibits JAK1 and JAK3, thereby blocking pro-inflammatory cytokine signaling, in particular interleukin (IL)-6 and interferon $\gamma[7,8]$. C-reactive protein (CRP), a marker of inflammation, is under the transcriptional control of IL-6 [9] and, thus, may be modulated by tofacitinib. Tofacitinib also modulates the activity of several other interleukins (including IL-2, $-4,-7,-9,-15$, and -21$)$ that have roles in mediating immune response to viral infection/reactivation, lymphocyte development, and effector function $[10,11]$. Owing to the chronic nature of 
psoriasis and consequent prolonged and repeated periods of exposure to systemic immunomodulatory therapies, it is important to evaluate the potential effects of new therapies, such as tofacitinib, on immunosurveillance.

This exploratory analysis investigated the effect of oral tofacitinib on lymphocyte sub-populations to identify any impact of tofacitinib on immunosurveillance during a Phase IIb, 12-week, placebo-controlled study in patients with moderate to severe plaque psoriasis [4]. The potential for reactivation of latent viruses (eg cytomegalovirus $[\mathrm{CMV}]$, John Cunningham virus, EpsteinBarr virus [EBV], hepatitis B virus, and varicella zoster virus) has been described with other immunosuppressive agents [12-17]. Recurrence of CMV infection in immunocompromised patients can cause damage to the digestive system, lungs, and eyes [18]. CMV infections have been reported in patients with psoriasis receiving biologic therapies including the tumor necrosis factor inhibitor (TNFi) etanercept, and efalizumab, an antiCD11a antibody [12,13]. Efalizumab was found to be associated with increased risk of John Cunningham virus -related progressive multifocal leukoencephalopathy, a potentially fatal infection of the central nervous system and, consequently, was withdrawn from the market in 2009 [19]. Reactivation of EBV is associated with development of lymphoproliferative malignancies including non-Hodgkin lymphoma, and has been reported in patients receiving biologic and nonbiologic treatment for psoriasis [14,15]. Reactivation of hepatitis B virus can lead to severe hepatitis, liver failure, and death [20]. A need for hepatitis B virus screening and pre-emptive therapy has been highlighted in patients receiving TNFi therapy [21]. Reactivation of latent varicella zoster virus causes shingles, the main complication of which is chronic pain, and is a long-term challenge in patients receiving immunosuppressive therapy [17].

In the present study, potential for viral reactivation in general was evaluated using CMV and EBV DNA copy numbers as surrogates of viral-specific immune surveillance. To complement evaluation of lymphocyte subpopulations during tofacitinib treatment, changes in inflammatory activity during tofacitinib treatment were assessed using serum levels of CRP as a marker.

\section{Methods}

This was a Phase IIb, randomized, double-blind, parallelgroup, placebo-controlled study conducted in 42 centers in the United States and Canada (NCT00678210). Patients were aged $\geq 18$ years with moderate to severe chronic plaque-type psoriasis covering $\geq 15 \%$ of the total body surface area, had stable disease for $\geq 6$ months, a Psoriasis Area and Severity Index (PASI) score $\geq 13$ and were eligible for phototherapy or systemic treatment of psoriasis [4]. Patients were excluded if they had received any prior lymphocyte-depleting therapy (eg alemtuzumab, cyclophosphamide, chlorambucil) or had received rituximab/other selective B lymphocyte-depleting therapy within the preceding 12 months.

The study design has been reported elsewhere [4]. Briefly, patients were randomized 1:1:1:1 to receive oral tofacitinib ( $2 \mathrm{mg}, 5 \mathrm{mg}$, or $15 \mathrm{mg}$ twice daily [BID]), or placebo, for 12 weeks. Follow-up continued for 4 weeks after study completion or withdrawal. The safety population (all patients who received at least one dose of tofacitinib or placebo) was used in this exploratory analysis. The study was performed in compliance with the International Conference on Harmonization Good Clinical Practice Guidelines. All patients provided written informed consent, and both consent documentation and the final protocol were reviewed and approved by the institutional review board and/or the independent ethics committee at each of the investigational centers participating in the study.

\section{Cell and viral quantification}

Whole blood and serum were collected and analyzed. Lymphocyte populations were identified and quantified by fluorescence-activated cell sorting (FACS) analysis at baseline, Weeks 4 and 12, or early termination. Lymphocyte subset markers analyzed included: $\mathrm{CD}^{+}$(total $\mathrm{T}$ cells), $\mathrm{CD}^{+} / \mathrm{CD}^{+}$( $\mathrm{T}$ helper cells; $\mathrm{T}_{\mathrm{H}}$ ), $\mathrm{CD}^{+} / \mathrm{CD}^{+}$(cytotoxic $\mathrm{T}$ cells; $\mathrm{T}_{\mathrm{C}}$ ), $\mathrm{CD} 19^{+}$(B cells), and $\mathrm{CD} 16^{+} / \mathrm{CD}^{+} 6^{+}$(natural killer cells; NK).

Serum CRP levels were measured at baseline and Week 12 or early termination. Blood CMV and EBV DNA was measured at baseline, Weeks 4 and 8 (CMV only), and Week 12 or early termination. Viral loads were quantified by real-time polymerase chain reaction (PCR) using DNA isolated directly from peripheral blood leukocytes and expressed as viral DNA copies/500 ng of total DNA. CMV or EBV DNA levels $>0$ copies/500 ng total DNA were defined as detectable.

\section{Statistical analysis}

For continuous endpoints measured longitudinally, a repeated mixed-effect model was used to analyze change from baseline, where treatment, visit week, and interaction between treatment and visit week were included as fixed factors, along with baseline value as the covariate. For continuous endpoints evaluated at a single time point, analysis of covariance (ANCOVA) was used to analyze change from baseline, and the baseline value was included as covariate. For categorical data, comparisons between groups were performed using a Chisquared test. Missing values were not imputed in any of these analyses.

Spearman's correlation analyses, based on the ranks of variables, were performed between change in viral load 
or CRP level, and change in lymphocyte sub-population cell counts. A linear model was used to assess potential relationships between change in viral load or CRP level, and change in lymphocyte sub-population cell counts, and doses of tofacitinib.

\section{Results}

Baseline demographics, disease characteristics, and laboratory values (including lymphocyte sub-population cell counts, CRP, CMV, and EBV viral load) were similar between groups (Table 1 ).

\section{Effects on T cells}

In patients receiving tofacitinib, there was a dosedependent percentage increase from baseline in median total $\mathrm{T}\left(\mathrm{CD}^{+}\right)$cell count at Week 4 , returning to near baseline levels by Week 12 (Table 2, Figure 1). Such a trend was not observed in patients receiving placebo.

A similar pattern of dose-dependent percentage increases at Week 4, followed by a return to near baseline levels at Week 12, was observed in median $\mathrm{T}_{\mathrm{H}}\left(\mathrm{CD}^{+} / \mathrm{CD}^{+}\right)$cell counts (Table 2, Figure 1). No patient had a $\mathrm{T}_{\mathrm{H}}$ cell count $<200$ cells $/ \mathrm{mm}^{3}$. Among patients with a $\mathrm{T}_{\mathrm{H}}$ cell count of $\geq 500$ cells $/ \mathrm{mm}^{3}$ at baseline $(n=170)$, two, two, one, and three patients receiving placebo, tofacitinib $2 \mathrm{mg}$, $5 \mathrm{mg}$, or $15 \mathrm{mg}$ BID, respectively, had a single post-baseline measurement of $<500$ cells $/ \mathrm{mm}^{3}$. Only one patient had two consecutive $\mathrm{T}_{\mathrm{H}}$ cell counts $<500$ cells $/ \mathrm{mm}^{3}$ (Week 4 and Week 12). This patient received tofacitinib $2 \mathrm{mg}$ BID. While there was some variability in $\mathrm{T}_{\mathrm{C}}\left(\mathrm{CD}^{+} / \mathrm{CD}^{+}\right)$cell counts, these changes did not appear to be dose dependent (Table 2, Figure 1).

Overall, there was a good correlation between total lymphocyte count and sub-population cell counts ( $T$ cells, $\mathrm{T}_{\mathrm{H}}$ cells, and $\mathrm{T}_{\mathrm{C}}$ cells) across groups, ranging from 0.62-0.93 at baseline, 0.58-0.94 at Week 4, and 0.560.92 at Week 12 .

\section{Effects on B cells}

Tofacitinib treatment resulted in dose-dependent percentage increases from baseline in B cell counts that were sustained throughout the study (Table 2, Figure 1). At Week 12 , five $(13.2 \%)$, two $(5.4 \%)$, and four (10.3\%) patients receiving tofacitinib $2 \mathrm{mg}, 5 \mathrm{mg}$, and $15 \mathrm{mg}$ BID, respectively, had B cell counts above the normal range, compared with one patient $(3.0 \%)$ in the placebo group.

\section{Effects on natural killer cells}

Treatment with tofacitinib resulted in dose-dependent percentage reductions from baseline in median NK cell count at Week 4. At Week 12 the median NK cell count reduced further in the tofacitinib $2 \mathrm{mg}$ BID group,

Table 1 Patient demographics, disease characteristics, cell counts, CMV and EBV DNA count at baseline

\begin{tabular}{|c|c|c|c|c|}
\hline & $\begin{array}{l}\text { Placebo } \\
(n=50)\end{array}$ & $\begin{array}{l}\text { Tofacitinib } 2 \mathrm{mg} \text { BID } \\
(\mathrm{n}=49)\end{array}$ & $\begin{array}{l}\text { Tofacitinib } 5 \mathrm{mg} \text { BID } \\
(\mathrm{n}=49)\end{array}$ & $\begin{array}{l}\text { Tofacitinib } 15 \mathrm{mg} \text { BID } \\
(\mathrm{n}=49)\end{array}$ \\
\hline Mean age, years (SD) & $43.9(13.0)$ & $45.7(13.8)$ & $44.0(12.6)$ & $43.6(15.6)$ \\
\hline Male, n (\%) & $36(72.0)$ & $29(59.2)$ & $29(59.2)$ & $31(63.2)$ \\
\hline White, n (\%) & $41(82.0)$ & $36(73.5)$ & $42(85.7)$ & $40(81.6)$ \\
\hline Mean weight, kg (SD) & $89.6(23.9)$ & $89.6(23.0)$ & $92.2(23.5)$ & $93.1(29.7)$ \\
\hline Mean PASI score (SD) & $21.5(7.1)$ & $21.5(6.7)$ & $21.2(8.1)$ & $22.6(10.3)$ \\
\hline Mean BSA, \% (SD) & $29.8(13.5)$ & $29.8(13.4)$ & $30.1(17.0)$ & $31.9(18.8)$ \\
\hline \multicolumn{5}{|l|}{ PGA, n (\%): } \\
\hline Mild & $6(12.0)$ & $8(16.3)$ & $11(22.4)$ & $9(18.8)$ \\
\hline Moderate & $41(82.0)$ & 39 (79.6) & $33(67.3)$ & $33(68.8)$ \\
\hline Severe & $3(6.0)$ & $2(4.1)$ & $5(10.2)$ & $6(12.5)$ \\
\hline \multicolumn{5}{|l|}{ Median cell counts, cells/mm³ (Q25, Q75): } \\
\hline $\mathrm{T}\left(\mathrm{CD}^{+}\right)$ & $1310(982,1517)$ & $1115(894,1455)$ & $1206(1047,1578)$ & $1162(935,1510)$ \\
\hline $\mathrm{T}_{\mathrm{H}}\left(\mathrm{CD}^{+} / \mathrm{CD}^{+}\right)$ & $802(615,975)$ & $730(572,931)$ & $868(637,998)$ & $744(597,950)$ \\
\hline $\mathrm{T}_{\mathrm{C}}\left(\mathrm{CD}^{+} / \mathrm{CD} 8^{+}\right)$ & $431(287,570)$ & $331(246,498)$ & $392(264,501)$ & $386(292,539)$ \\
\hline $\mathrm{B}\left(\mathrm{CD} 19^{+}\right)$ & $195(134,304)$ & $241(136,322)$ & $198(163,300)$ & $247(143,343)$ \\
\hline $\mathrm{NK}\left(\mathrm{CD} 16^{+} / \mathrm{CD} 6^{+}\right)$ & $159(93,188)$ & $135(91,214)$ & $130(95,207)$ & $152(97,216)$ \\
\hline Median CMV viral load, copies/500 ng total DNA (Q25, Q75) & $0(0.00,0.00)$ & $0(0.00,0.00)$ & $0(0.00,0.00)$ & $0(0.00,0.00)$ \\
\hline Median EBV viral load, copies/500 ng total DNA (Q25, Q75) & $0(0.00,1.30)$ & $0(0.00,0.95)$ & $0(0.00,1.00)$ & $0(0.00,0.85)$ \\
\hline Median CRP, mg/L (Q25, Q75) & $1.84(0.83,4.41)$ & $2.54(1.13,7.79)$ & $1.92(1.02,5.84)$ & $3.14(0.92,7.86)$ \\
\hline
\end{tabular}

B, B cells; BSA, body surface area; BID, twice daily; CMV, cytomegalovirus; CRP, C-reactive protein; DNA, deoxyribonucleic acid; EBV, Epstein-Barr virus; $\mathrm{n}$, number; NK, natural killer cells; PASI, Psoriasis Area and Severity Index; PGA, Physician's Global Assessment (scored on a five-point severity scale); Q, quartile; $\mathrm{SD}$, standard deviation; $\mathrm{T}$, total $\mathrm{T}$ cells; $\mathrm{T}_{\mathrm{C}}$, cytotoxic $\mathrm{T}$ cells; $\mathrm{T}_{\mathrm{H}}$, $\mathrm{T}$ helper cells. 
Table 2 Change from baseline in lymphocyte sub-populations, EBV and CMV DNA counts, and CRP ${ }^{a}$

\begin{tabular}{|c|c|c|c|c|c|}
\hline \multicolumn{6}{|c|}{ Median percent change in lymphocyte sub-population cell counts, cells/mm $\mathrm{mm}^{3}(\mathrm{Q} 25, \mathrm{Q} 75)$} \\
\hline & Time point & Placebo & Tofacitinib & Tofacitinib & Tofacitinib \\
\hline & & & $2 \mathrm{mg}$ BID & 5 mg BID & $15 \mathrm{mg}$ BID \\
\hline \multirow[t]{2}{*}{$\mathrm{T}\left(\mathrm{CD}^{+}\right)$} & Week 4 & $-0.39(-14.03,9.75)$ & $4.79(-7.45,17.57)$ & $6.36(-4.05,24.24)$ & $8.38(-9.07,42.80)$ \\
\hline & Week 12 & $2.28(-8.31,11.10)$ & $0.10(-17.18,15.87)$ & $3.73(-11.75,17.54)$ & $0.65(-23.86,17.64)$ \\
\hline \multirow[t]{2}{*}{$\mathrm{T}_{\mathrm{H}}\left(\mathrm{CD}^{+} / \mathrm{CD}^{+}\right)$} & Week 4 & $-0.14(-10.71,12.20)$ & $5.52(-6.73,18.12)$ & $9.56(0,30.24)$ & $15.09(-5.39,56.12)$ \\
\hline & Week 12 & $0.89(-7.00,15.95)$ & $-0.90(-12.29,15.42)$ & $3.82(-9.54,17.99)$ & $-0.82(-22.29,32.57)$ \\
\hline \multirow[t]{2}{*}{$\mathrm{T}_{\mathrm{C}}\left(\mathrm{CD}^{+} / \mathrm{CD}^{+}\right)$} & Week 4 & $-4.79(-12.42,15.01)$ & $5.13(-13.33,19.62)$ & $0.29(-9.45,27.35)$ & $-0.23(-19.05,47.92)$ \\
\hline & Week 12 & $3.74(-11.43,18.42)$ & $-5.58(-16.27,11.29)$ & $-1.48(-12.46,14.07)$ & $-0.33(-28.53,24.61)$ \\
\hline \multirow[t]{2}{*}{$\mathrm{B}\left(\mathrm{CD} 19^{+}\right)$} & Week 4 & $-6.87(-19.05,11.40)$ & $23.88(6.60,43.13)$ & $45.17(16.28,56.84)$ & $67.90(32.64,103.79)$ \\
\hline & Week 12 & $-0.67(-12.93,18.09)$ & $18.03(0.94,47.37)$ & $35.32(9.66,66.32)$ & $42.86(16.74,67.50)$ \\
\hline \multirow[t]{2}{*}{$\mathrm{NK}\left(\mathrm{CD} 16^{+} / \mathrm{CD} 6^{+}\right)$} & Week 4 & $0(-27.68,37.60)$ & $-10.94(-28.17,8.28)$ & $-26.11(-46.71,4.35)$ & $-40.80(-52.50,-10.06)$ \\
\hline & Week 12 & $13.87(-21.43,26.67)$ & $-20.00(-34.17,3.97)$ & $-22.76(-51.38,-1.59)$ & $-34.31(-57.07,-16.57)$ \\
\hline \multicolumn{6}{|c|}{ Median change in viral load, copies/500 ng total DNA (Q25, Q75) } \\
\hline \multirow[t]{3}{*}{ CMV } & Week 4 & $0(0.00,0.00)$ & $0(0.00,0.00)$ & $0(0.00,0.00)$ & $0(0.00,0.00)$ \\
\hline & Week 8 & $0(0.00,0.00)$ & $0(0.00,0.00)$ & $0(0.00,0.00)$ & $0(0.00,0.90)$ \\
\hline & Week 12 & $0(0.00,0.00)$ & $0(0.00,0.00)$ & $0(0.00,0.00)$ & $0(0.00,0.00)$ \\
\hline EBV & Week 12 & $0(-1.10,0.00)$ & $0(0.00,1.25)$ & $0(0.00,0.60)$ & $0.70(0.00,2.90)$ \\
\hline \multicolumn{6}{|c|}{ Median percent change in CRP, \% (Q25, Q75) } \\
\hline CRP & Week 12 & $9.42(-52.41,61.08)$ & $-24.71(-47.43,5.49)$ & $-36.31(-74.62,5.49)$ & $-69.17(-82.20,-34.38)$ \\
\hline
\end{tabular}

remained similar in the tofacitinib $5 \mathrm{mg}$ BID group, and increased in the tofacitinib $15 \mathrm{mg}$ BID group (Table 2, Figure 1).

\section{Changes in C-reactive protein levels}

Median CRP values at baseline are shown in Table 1. At Week 12, there were dose-dependent percentage reductions from baseline in median CRP levels in the tofacitinib groups, whereas CRP increased in the placebo group (Table 2).

\section{Cytomegalovirus and Epstein-Barr virus DNA}

The median (quartile [Q]25, Q75) CMV viral load at baseline was 0 copies/500 ng total DNA $(0.0,0.0)$ in all groups. The median change from baseline in CMV DNA was 0 copies $/ 500 \mathrm{ng}$ total DNA at Week 4, Week 8, and Week 12 (the Q25 and Q75 were 0.0 for all groups and time points except for the tofacitinib $15 \mathrm{mg}$ BID group at Week 8, in which the Q75 value was 0.9) (Table 2, Figure 2).

CMV DNA was detected in three patients at baseline: one each in the placebo, tofacitinib $2 \mathrm{mg}$, and tofacitinib $5 \mathrm{mg}$ BID groups. In all three patients, the CMV viral load was $<1$ copy/500 ng total DNA. Only one patient, a 78-year-old white male receiving tofacitinib $15 \mathrm{mg}$ BID, had post-baseline incidences of CMV DNA >10 copies/
500 ng total DNA, which were as follows. This patient had a positive test for CMV on Day 57 (150 copies/500 ng total DNA), which was reported as a mild adverse event. He reported no other adverse signs or symptoms at this time and continued study treatment. CMV levels subsequently reduced to 92 copies/500 ng total DNA at Day 70 while on treatment. Once the initial positive test was relayed to the investigator site, study treatment was discontinued on Day 86, and on Day 87 his CMV level was 19 copies/500 ng total DNA. The event subsequently resolved. Another patient had a single incidence of CMV DNA $\geq 5$ copies $/ 500 \mathrm{ng}$ total DNA. This patient received tofacitinib $15 \mathrm{mg}$ BID, and had a CMV viral load of 7 copies/500 ng total DNA at Week 8, with no adverse events reported. The patient discontinued treatment and the elevated CMV levels resolved.

No comparison of baseline vs post-baseline CMV detectability was possible for patients with detectable CMV at baseline, due to limited sample size (Tables 1 and 3). In patients with undetectable CMV at baseline, tofacitinib was associated with detectable CMV at one or more time points post-baseline (Chi-squared test, $\mathrm{p}=0.0001$; Table 3). When individual tofacitinib groups were evaluated, the number of patients in whom CMV became detectable post-baseline was significant in the tofacitinib $15 \mathrm{mg}$ BID group only ( $\mathrm{p}=0.004$ vs placebo). 


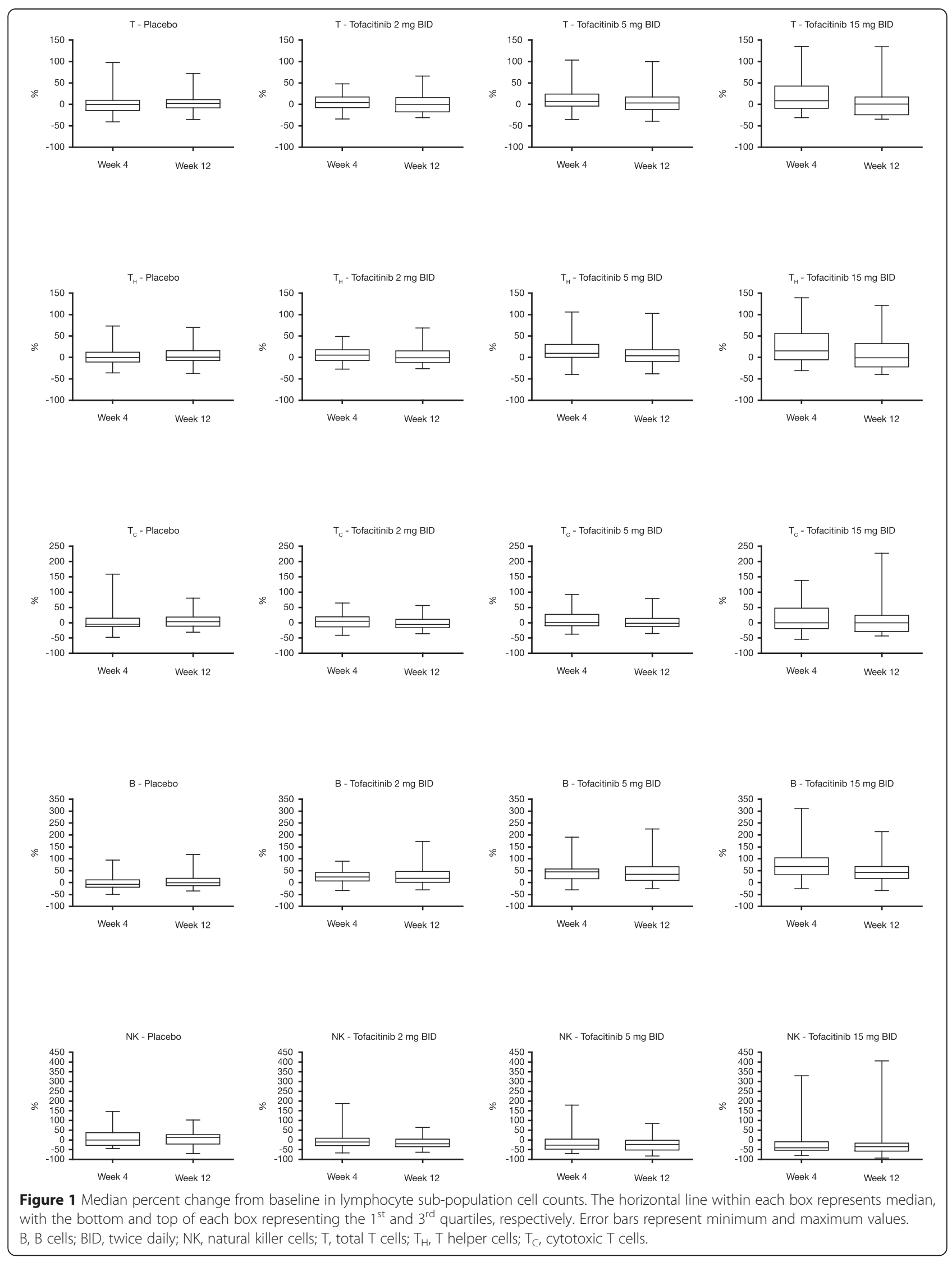




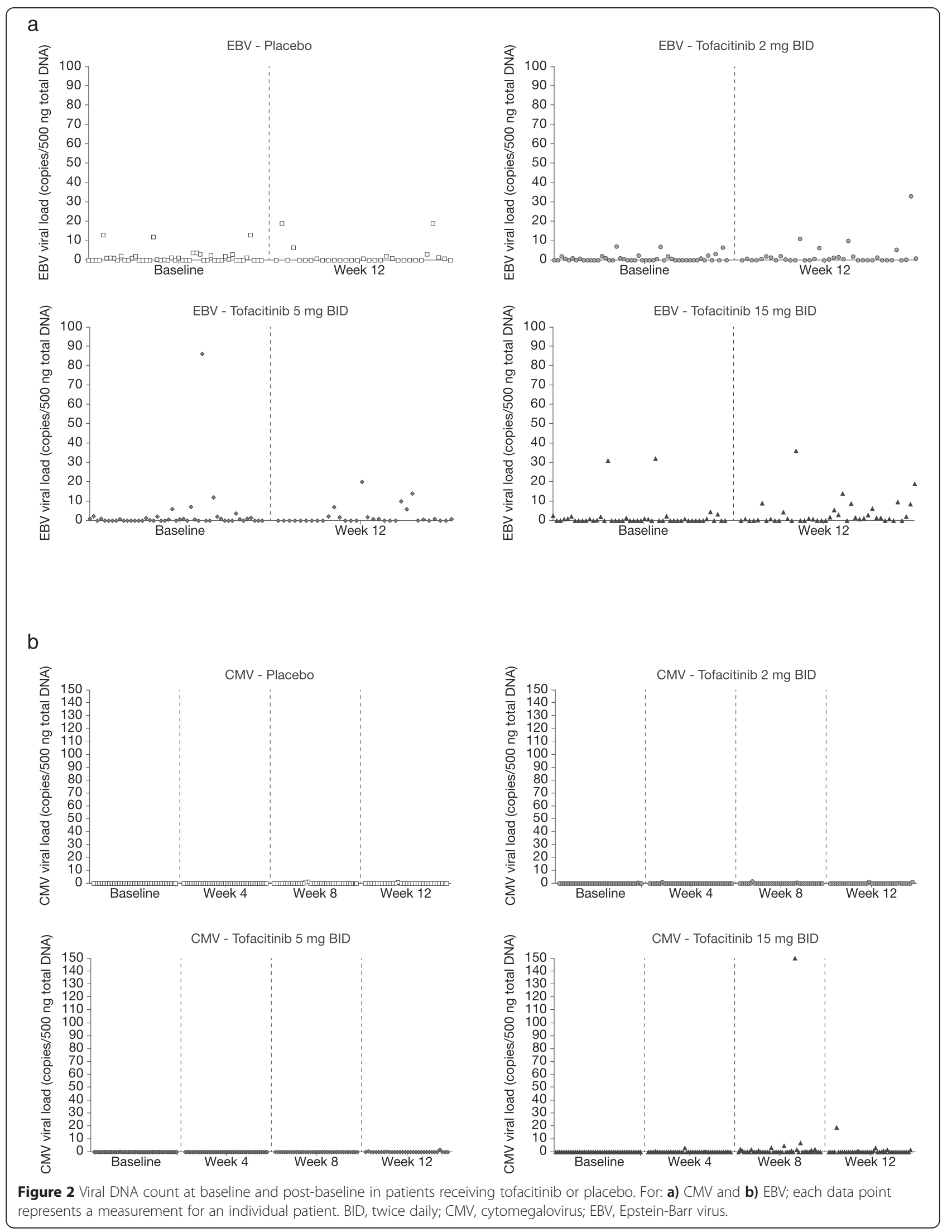


Table 3 Changes from baseline in CMV and EBV viral load in patients receiving placebo or tofacitinib 2 mg, 5 mg or 15 mg BID

\begin{tabular}{|c|c|c|c|c|c|}
\hline & Baseline status & Post-baseline status & & $\begin{array}{l}\text { Chi-squared } p \text { value } \\
\text { (vs placebo) }\end{array}$ & $\begin{array}{l}\text { Overall } p \text { value } \\
\text { (vs baseline) }\end{array}$ \\
\hline $\begin{array}{l}\text { Patients with } \mathrm{CMV} \text { undetectable } \\
\text { at baseline }\end{array}$ & $\begin{array}{l}\text { Undetectable } \\
N(n)\end{array}$ & $\begin{array}{l}\text { Remained undetectable } \\
\text { n (\%) }\end{array}$ & $\begin{array}{l}\text { Became detectable } \\
\text { n (\%) }\end{array}$ & & \\
\hline Placebo & $49(46)$ & $44(95.7)$ & $2(4.3)$ & N/A & 0.0001 \\
\hline Tofacitinib 2 mg BID & $48(46)$ & $41(89.1)$ & $5(10.9)$ & 0.2381 & \\
\hline Tofacitinib 5 mg BID & $48(45)$ & $42(93.3)$ & $3(6.7)$ & 0.6274 & \\
\hline Tofacitinib 15 mg BID & $49(48)$ & $32(66.7)$ & $16(33.3)$ & 0.0004 & \\
\hline $\begin{array}{l}\text { Patients with CMV detectable } \\
\text { at baseline }^{a}\end{array}$ & $\begin{array}{l}\text { Detectable } \\
N(n)\end{array}$ & $\begin{array}{l}\text { Remained detectable } \\
\mathrm{n}(\%)\end{array}$ & $\begin{array}{l}\text { Became undetectable } \\
\text { n (\%) }\end{array}$ & & \\
\hline Placebo & $1(1)$ & $0(0)$ & $1(100.0)$ & N/A & - \\
\hline Tofacitinib 2 mg BID & $1(1)$ & $0(0)$ & $1(100.0)$ & - & \\
\hline Tofacitinib 5 mg BID & $1(1)$ & $0(0)$ & $1(100.0)$ & - & \\
\hline Tofacitinib 15 mg BID & $0(0)$ & $0(0)$ & $0(0)$ & - & \\
\hline $\begin{array}{l}\text { Patients with EBV undetectable } \\
\text { at baseline }\end{array}$ & $\begin{array}{l}\text { Undetectable } \\
N(n)\end{array}$ & $\begin{array}{l}\text { Remained undetectable } \\
\mathrm{n}(\%)\end{array}$ & $\begin{array}{l}\text { Became detectable } \\
\text { n (\%) }\end{array}$ & & \\
\hline Placebo & $28(20)$ & $18(90.0)$ & $2(10.0)$ & N/A & 0.0122 \\
\hline Tofacitinib 2 mg BID & $30(25)$ & $14(56.0)$ & $11(44.0)$ & 0.0124 & \\
\hline Tofacitinib 5 mg BID & $26(19)$ & $15(78.9)$ & $4(21.1)$ & 0.3390 & \\
\hline Tofacitinib 15 mg BID & $31(28)$ & $14(50.0)$ & $14(50.0)$ & 0.0038 & \\
\hline $\begin{array}{l}\text { Patients with EBV detectable } \\
\text { at baseline }\end{array}$ & $\begin{array}{l}\text { Detectable } \\
N(n)\end{array}$ & $\begin{array}{l}\text { Remained detectable } \\
\text { n (\%) }\end{array}$ & $\begin{array}{l}\text { Became undetectable } \\
\text { n (\%) }\end{array}$ & & \\
\hline Placebo & $21(19)$ & $9(47.4)$ & $10(52.6)$ & N/A & 0.1299 \\
\hline Tofacitinib 2 mg BID & $18(13)$ & $9(69.2)$ & $4(30.8)$ & 0.2208 & \\
\hline Tofacitinib 5 mg BID & $21(14)$ & $10(71.4)$ & $4(28.6)$ & 0.1669 & \\
\hline Tofacitinib 15 mg BID & $17(14)$ & $12(85.7)$ & $2(14.3)$ & 0.0236 & \\
\hline
\end{tabular}

${ }^{a}$ A statistical comparison of change in CMV detectability from detectable at baseline to undetectable post-baseline was not possible due to limited sample size. BID, twice daily; CMV, cytomegalovirus; EBV, Epstein-Barr virus; N, number of patients with baseline values; $n$, number of patients with baseline and post-baseline values; N/A, not applicable.

The median (Q25, Q75) EBV viral load at baseline was 0.0 copies $/ 500 \mathrm{ng}$ total DNA $(0.0,1.3)$ in all groups (Table 1). Twelve patients had baseline EBV DNA $\geq 5$ copies/500 ng total DNA: three receiving placebo, and three, four, and two patients receiving tofacitinib $2 \mathrm{mg}, 5 \mathrm{mg}$, and $15 \mathrm{mg}$ BID, respectively. Of these, seven patients (three in the placebo group, and two each in the tofacitinib $5 \mathrm{mg}$ and $15 \mathrm{mg}$ BID groups) had EBV DNA $>10$ copies/500 ng total DNA. The highest EBV DNA value at baseline (86 copies/500 ng total DNA) was reported for a patient in the tofacitinib $5 \mathrm{mg}$ BID group. This patient had a mild, upper respiratory tract infection at study entry, which began 12 days before treatment and resolved on Day 15.

At Week 12, the median (Q25, Q75) change from baseline in EBV viral load was $0(-1.1,1.3)$ for all groups except for the tofacitinib $15 \mathrm{mg}$ BID group, in which the median EBV DNA count increased by 0.7 copies/500 ng total DNA $(0.0,2.9)$ (Table 2). Twenty-two patients had EBV DNA $\geq 5$ copies/500 ng total DNA at Week 12: three receiving placebo, and five, five, and nine patients receiving tofacitinib $2 \mathrm{mg}, 5 \mathrm{mg}$, and $15 \mathrm{mg} \mathrm{BID}$, respectively. Of these, nine patients (two each in the placebo, tofacitinib $2 \mathrm{mg}$, and $5 \mathrm{mg}$ BID groups, and three in the tofacitinib $15 \mathrm{mg}$ BID group) had EBV DNA $>10$ copies/500 ng total DNA. The highest EBV DNA values at Week 12 were reported for a patient receiving tofacitinib $2 \mathrm{mg}$ BID and a patient receiving tofacitinib $15 \mathrm{mg}$ BID (33 copies and 36 copies/500 ng total DNA, respectively). Both had EBV levels $\geq 5$ copies/500 ng total DNA at baseline. The patient with EBV levels of 33 copies/500 ng total DNA had adverse events of increased low-density lipoprotein and increased blood cholesterol reported at that time point. The patient with EBV DNA 36 copies/500 ng total DNA had no adverse events reported.

Overall, in patients with undetectable EBV at baseline, tofacitinib was associated with detectable EBV at Week 12 (Chi-squared test, $\mathrm{p}=0.0122$ ). The number of patients in whom EBV became detectable post-baseline 
was significant vs placebo in the tofacitinib $2 \mathrm{mg}$ BID $(\mathrm{p}=0.0124)$ and $15 \mathrm{mg}$ BID $(\mathrm{p}=0.0038)$ groups (Table 3$)$. However, there was also a significant proportion of patients in the tofacitinib $15 \mathrm{mg}$ BID group who had detectable EBV at baseline and undetectable EBV at Week $12(\mathrm{p}=0.0236$ vs placebo) (Table 3$)$.

\section{Correlation analyses}

Spearman's rank correlation coefficient (rho) analyses of pooled patient data showed that EBV viral load, but not CMV viral load, was weakly correlated with larger changes in total $\mathrm{T}$ cell, $\mathrm{T}_{\mathrm{H}}$ cell, $\mathrm{T}_{\mathrm{C}}$ cell, and $\mathrm{B}$ cell counts after 12 weeks of treatment (rho: 0.19, 0.20, 0.17, and 0.25, respectively). Changes in CRP level showed a weak inverse correlation with larger changes in total $\mathrm{T}$ cell, $\mathrm{T}_{\mathrm{H}}$ cell, $\mathrm{T}_{\mathrm{C}}$ cell, and $\mathrm{B}$ cell counts after 12 weeks of treatment (rho: $-0.28,-0.26,-0.20$, and -0.40 , respectively) (Table 4).

Potential correlations between tofacitinib dose, lymphocyte sub-population cell counts, CMV and EBV viral load, and CRP level were evaluated. Multivariate analyses using a general linear model detected no correlation between change in CMV or EBV viral load and lymphocyte subpopulations or dose of tofacitinib (Table 5). However, there was strong and significant correlation between change in CRP levels and change in $\mathrm{T}_{C}$ cell count $(\mathrm{p}=0.043)$ or dose of tofacitinib $(\mathrm{p}=0.026)$ (Table 5).

\section{Discussion}

Clinical data describing the impact of immunosuppressive therapies on the overall risk of infection and serious infection are limited in patients with psoriasis compared with rheumatoid arthritis (RA). However, there is emerging evidence to suggest that the infection risk associated with various therapies used in the RA setting may not be replicated in the psoriasis setting [22-24]. Moreover, effects of psoriasis therapies on immunosurveillance may vary according to the mechanism of action for each agent.

In this investigation, there was no clinically significant relationship between changes in CMV or EBV viral load and changes in lymphocyte sub-populations. Minimal and transient effects on $\mathrm{T}$ cell counts were identified in patients receiving tofacitinib, which may be related to modulation of cytokines, resultant modulation of adhesion molecules, and consequent trafficking of $\mathrm{T}$ cells. This is supported by dose-dependent percent changes from baseline in median total $\mathrm{T}$ cell $\left(\mathrm{CD}^{+}\right)$count at Week 4 , which appeared to normalize across all doses by Week 12. Dosedependent percentage changes in median $\mathrm{B}$ cell and NK cell count were observed with tofacitinib treatment, with B cell count increased from baseline and NK cell count decreased from baseline at Week 12. Overall, changes in lymphocyte sub-populations observed in this study appear consistent with observations in patients receiving tofacitinib for RA [25].

$\mathrm{T}_{\mathrm{H}}$ cell counts correlated well with total lymphocyte counts over time, suggesting that tofacitinib does not change the $\mathrm{T}_{\mathrm{H}}$ cell distribution. A $\mathrm{T}_{\mathrm{H}}$ cell count $<200$ cells $/ \mathrm{mm}^{3}$, which is a known risk factor for opportunistic infections in patients with human immunodeficiency virus (HIV) [26] was not observed in any patient in the present study. In addition, excluding those patients with a $\mathrm{T}_{\mathrm{H}}$ cell count $<500$ cells $/ \mathrm{mm}^{3}$ at baseline, fewer than $5 \%$ of patients in each group had a postbaseline $\mathrm{T}_{\mathrm{H}}$ cell count $<500$ cells $/ \mathrm{mm}^{3}$. In other settings in which patients may be immunocompromised, including bone marrow transplantation, a significant correlation with the occurrence of opportunistic infection has been observed only in patients with a $\mathrm{T}_{\mathrm{H}}$ cell count below 115 cells $/ \mathrm{mm}^{3}[27,28]$. Based on data collected during this study, there is no need to routinely monitor levels of lymphocyte sub-populations in patients receiving tofacitinib therapy for plaque psoriasis. However, longer-term observation would be needed to confirm these findings.

In the present study, mean baseline CRP levels for each group ranged from 3.10 to $5.47 \mathrm{mg} / \mathrm{L}$, which is above the $3.0 \mathrm{mg} / \mathrm{L}$ threshold for high relative risk of cardiovascular disease [29]. Tofacitinib therapy was associated with dosedependent reductions in CRP at Week 12, reflecting the anti-inflammatory activity of tofacitinib. This is supported by the significant correlation between tofacitinib dose and changes in CRP. Furthermore, the observed, transient increase from baseline in peripheral lymphocytes in patients receiving tofacitinib, and the inverse correlation between changes in CRP level and larger changes in $\mathrm{T}$ cell, $\mathrm{T}_{\mathrm{H}}$ cell,

Table 4 Spearman's rank correlation coefficients between change from baseline to week 12 in CMV or EBV viral load, or CRP level, and change in lymphocyte sub-populations

\begin{tabular}{|c|c|c|c|c|c|}
\hline \multirow{2}{*}{$\begin{array}{l}\text { Change in outcome variables, rho } \\
\text { ( } p \text { value) }\end{array}$} & \multicolumn{5}{|c|}{ Lymphocyte sub-populations } \\
\hline & $\mathrm{T}\left(\mathrm{CD}^{+}\right)$ & $\mathrm{T}_{\mathrm{H}}\left(\mathrm{CD}^{+} / \mathrm{CD}^{+}\right)$ & $\mathrm{T}_{\mathrm{C}}\left(\mathrm{CD3}^{+} / \mathrm{CD}^{+}\right)$ & $\mathrm{B}\left(\mathrm{CD} 19^{+}\right)$ & NK $\left(\mathrm{CD} 16^{+} / \mathrm{CD} 56^{+}\right)$ \\
\hline CMV viral load, copies/500 ng total DNA & $-0.0499(0.5742)$ & $-0.0889(0.3164)$ & $0.0020(0.9817)$ & $-0.0530(0.5505)$ & $-0.0148(0.8674)$ \\
\hline EBV viral load, copies/500 ng total DNA & $0.1872(0.0351)$ & $0.1970(0.0264)$ & $0.1711(0.0544)$ & $0.2491(0.0047)$ & $0.0033(0.9709)$ \\
\hline CRP level, mg/L & $-0.2832(0.0008)$ & $-0.2644(0.0017)$ & $-0.2009(0.0181)$ & $-0.3996(0.0000)$ & $0.0699(0.4152)$ \\
\hline
\end{tabular}

The correlation analyses presented above were performed using pooled data from the placebo and tofacitinib groups.

B, B cells; CMV, cytomegalovirus; CRP, C-reactive protein; DNA, deoxyribonucleic acid; EBV, Epstein-Barr virus; NK, natural killer cells; rho, Spearman's rank correlation coefficient; $T$, total $T$ cells; $T_{H}$, $T$ helper cells; $T_{C}$, cytotoxic $T$ cells. 


\begin{tabular}{|c|c|c|c|c|c|c|c|}
\hline \multirow[t]{3}{*}{ Change in response variables } & & \multicolumn{6}{|c|}{ Explanatory variables } \\
\hline & & \multirow{2}{*}{$\begin{array}{l}\text { Dose of } \\
\text { tofacitinib }^{a}\end{array}$} & \multicolumn{5}{|c|}{ Lymphocyte sub-populations } \\
\hline & & & $\mathrm{T}\left(\mathrm{CD}^{+}\right)$ & $\mathrm{T}_{\mathrm{H}}\left(\mathrm{CD3}^{+} / \mathrm{CD}^{+}\right)$ & $\mathrm{T}_{\mathrm{C}}\left(\mathrm{CD3}^{+} / \mathrm{CDB}^{+}\right)$ & $\mathrm{B}\left(\mathrm{CD} 19^{+}\right)$ & NK $\left(\mathrm{CD} 16^{+} / \mathrm{CD}^{2} 6^{+}\right)$ \\
\hline \multirow[t]{3}{*}{ CMV viral load, copies/500 ng total DNA } & df & 3 & 1 & 1 & 1 & 1 & 1 \\
\hline & F value & 1.26 & 0.14 & 0.04 & 0.68 & 0.00 & 0.03 \\
\hline & $p$ value & 0.2926 & 0.7047 & 0.8411 & 0.4112 & 0.9925 & 0.8592 \\
\hline \multirow[t]{3}{*}{ EBV viral load, copies/500 ng total DNA } & $d f$ & 3 & 1 & 1 & 1 & 1 & 1 \\
\hline & F value & 0.50 & 0.54 & 1.69 & 0.11 & 0.02 & 0.57 \\
\hline & $p$ value & 0.6807 & 0.4627 & 0.1955 & 0.7430 & 0.8906 & 0.4501 \\
\hline \multirow[t]{3}{*}{ CRP level, mg/L } & $d f$ & 3 & 1 & 1 & 1 & 1 & 1 \\
\hline & F value & 3.18 & 1.45 & 1.84 & 4.18 & 0.11 & 1.83 \\
\hline & $p$ value & 0.0262 & 0.2315 & 0.1775 & 0.0430 & 0.7450 & 0.1784 \\
\hline
\end{tabular}

${ }^{a}$ Doses of tofacitinib considered in this analysis were $0 \mathrm{mg}, 2 \mathrm{mg}, 5 \mathrm{mg}$, and $15 \mathrm{mg}$ BID.

B, B cells; BID, twice daily; CMV, cytomegalovirus; CRP, C-reactive protein; df, degrees of freedom; DNA, deoxyribonucleic acid; EBV, Epstein-Barr virus; NK, natural killer cells; $\mathrm{T}$, total $\mathrm{T}$ cells; $\mathrm{T}_{\mathrm{H}}, \mathrm{T}$ helper cells; $\mathrm{T}_{\mathrm{C}}$, cytotoxic $\mathrm{T}$ cells.

$\mathrm{T}_{\mathrm{C}}$ cell, and $\mathrm{B}$ cell counts after 12 weeks of treatment, is consistent with the recruitment of lymphocytes to sites of inflammation and release of lymphocytes as inflammation resolves.

There is published evidence to suggest an association between active plaque psoriasis and reactivation of CMV, with one study identifying a correlation between psoriasis disease activity in CMV seropositive patients and severity of CMV-antigenemia [30]. In the present study, there was an overall association between tofacitinib and post-baseline detectability of CMV and EBV DNA, and significant changes in CMV and EBV detectability in the tofacitinib $2 \mathrm{mg}$ and $15 \mathrm{mg}$ BID groups (vs placebo). When considered alongside viral load measurements for individual patients, in most cases, changes in CMV and EBV detectability are likely to reflect only subtle differences in viral load. Indeed, a multivariate analysis showed no correlation between viral load and dose of tofacitinib. Considering the important role of $\mathrm{T}$ cells and NK cells in the response to viral infection [31,32], this finding implies that the modest changes in lymphocyte sub-populations observed during 12 weeks of tofacitinib therapy did not translate into clinically significant changes in effective immunosurveillance. Moreover, the lack of changes in viral load also suggests that $\mathrm{T}$ cell function, critical for control of viral infections [33], is preserved in patients treated with tofacitinib, at least over the course of 12 weeks. This conclusion is supported by the case of one patient with a treatmentemergent adverse event of elevated CMV, whose CMV levels reduced before stopping treatment and who did not develop any clinical symptoms.

In the HIV setting, a CMV viral load of $>200$ copies $/ \mathrm{mL}$ predicts the future occurrence of CMV end organ disease [34]. There is no single treatment threshold for CMV in the transplant setting. However, a CMV viral load cut-off of 5000 copies/mL for pre-emptive therapy was described in a recent study investigating CMV reactivation in 161 liver transplant patients [35]. In another study involving 28 liver transplant patients, the median viral load associated with symptomatic CMV disease was 230,000 copies/mL [36]. These levels are substantially in excess of the maximum CMV level reported in any patient in this study.

There are few published studies describing the effects of other therapies for RA or psoriasis on CMV or EBV viral load. A study with 62 patients, aged 2-28 years, receiving biologic (including infliximab and etanercept) or nonbiologic treatment for juvenile RA, Crohn's disease, or ulcerative rectocolitis detected CMV DNA in $1.6 \%$ of patients and EBV in $4.8 \%$ of patients [37]. All but one patient with detectable CMV or EBV had received nonbiologic therapy in the preceding year. Neither CMV nor EBV DNA was detected in the control group, which comprised 62 healthy volunteers. However, the extent to which viral load was related to the underlying disease or the treatment received was unclear [37]. A study of EBV viral load in 122 patients receiving biologic agents, including TNFi, for inflammatory arthritis found that $90 \%$ of patients receiving active treatment (and 98\% of biologic-naïve controls) had a positive antibody test for EBV during treatment, although subsequent PCR testing revealed no evidence of viral activation [38]. In addition, Niemann and colleagues detected no EBV DNA in 26 patients with psoriasis who received at least eight weeks of treatment with various nonbiologic and biologic agents (methotrexate, cyclosporine, etanercept, or alefacept) [39]. It should be noted that our investigation, and 
the above studies by McKeown and Niemann et al., measured viral load in patients who were asymptomatic for infection with CMV or EBV. In other indications where immunosuppressive therapy is used, such as RA and transplantation, an associated risk of viral infections has been observed [40], although the duration of treatment in that study was substantially longer than the 12-week duration of tofacitinib therapy in this study. Thus, the available evidence suggests that, while CMV or EBV DNA may become detectable in some patients during treatment with biologic or nonbiologic therapy for inflammatory diseases such as plaque psoriasis, viral reactivation and symptomatic clinical infections are rare.

Potential limitations of this analysis were the duration of exposure to tofacitinib (12 weeks) and the use of lymphocyte subsets (CD4 and CD8) as surrogates of virus-specific CD4+ and CD8+ cells. While no effect of tofacitinib exposure on viral load was observed over the 12 -week study period, one cannot be certain that such an effect would not be observed over a more prolonged period of exposure. With regard to lymphocyte subsets it is possible, albeit unlikely, that tofacitinib treatment could affect the number or function of virus-specific cells without markedly affecting the total number of cells. The absence of an observed increase in viral load suggests that the number and function of these virusspecific cells was sufficient to control viral replication.

\section{Conclusions}

In patients with psoriasis, 12 weeks of tofacitinib treatment had no clinically significant effects on CMV or EBV viral load, suggesting that lymphocyte sub-populations critical to the response to chronic viral infections and viral reactivation were not significantly affected. Replication of these findings during long-term use of tofacitinib will allow confirmation of this observation.

\footnotetext{
Abbreviations

ANCOVA: Analysis of covariance; B: B cells; BID: Twice daily; BSA: Body surface area; CMV: Cytomegalovirus; CRP: C-reactive protein; df: Degrees of freedom; DNA: Deoxyribonucleic acid; EBV: Epstein-Barr virus; HIV: Human immunodeficiency virus; IL: Interleukin; JAK: Janus kinase; N/A: Not applicable; NK: Natural killer cell; PASI: Psoriasis Area and Severity Index; PGA: Physician's Global Assessment; Q: Quartile; RA: Rheumatoid arthritis; rho: Spearman's rank correlation coefficient; SD: Standard deviation; T: Total T cells; $\mathrm{T}_{C}$ : Cytotoxic T cell; $\mathrm{T}_{\mathrm{H}}: \mathrm{T}$ helper cell; TNFi: Tumor necrosis factor inhibitor.
}

\section{Competing interests}

Fernando Valenzuela has been a principal investigator, member of a scientific advisory board or speaker for AbbVie, Eli Lilly, Janssen, Merck, Novartis, and Pfizer Inc. Kim A Papp has been a principal investigator, an advisor or consultant, a Scientific Officer, member of a Scientific Advisory Board and a speaker for Abbott, Amgen, Astellas, Celgene, Centocor-Ortho Biotech, Incyte, Isotechnika, Janssen, Lilly, Medimmune, Merck, Novartis, and Pfizer Inc. David Pariser has been a principal investigator, advisor or consultant for Abbott/AbbVie, Amgen, Astellas, Celgene, Eli Lilly, Janssen-Ortho, Novartis, Pfizer Inc, and Valeant. Stephen K Tyring has conducted research funded by Pfizer Inc. At the time of this analysis, Jeff Wang was an employee of Quintiles, and acted as a paid consultant to Pfizer Inc in connection with the analysis of study data. Robert Wolk, Marjorie Buonanno, Huaming Tan, and Hernan Valdez are employees and stockholders of Pfizer Inc.

\section{Authors' contributions}

KAP enrolled and examined patients during the course of the study. The data analysis was planned by HV and $\mathrm{HT}$, and executed by HT and JW. FV, DP, SKT, RW and MB contributed to the interpretation of data. All authors contributed to the development of the manuscript and provided critical input at all stages of development. All authors read and approved the final manuscript.

\section{Acknowledgments}

This work was supported by Pfizer Inc. Medical writing support was provided by Claire Cridland at Complete Medical Communications and was funded by Pfizer Inc. The authors would like to thank the patients who were involved in this study, as well as the investigators and study teams.

\section{Previous presentations of the data contained in this manuscript}

Sociedad Latinoamericana de Psoriasis (SOLAPSO) 2012. Valenzuela F, Papp K, Pariser D, Tyring S, Wolk R, Buonanno M, Valdez H. Effects of Tofacitinib on Lymphocyte Subpopulations, and CMV and EBV Viral Load, in Patients with Plaque Psoriasis. Buenos Aires; November 30-December 2, 2012, Abstract and Poster \#81.

Congress of International Investigative Dermatology (IID), 2013. Valenzuela F, Papp K, Pariser D, Tyring S, Wolk R, Buonanno M, Valdez H. Tofacitinib has no clinically significant effects on cells controlling chronic viral infection and reactivation. Journal of International Investigative Dermatology 2013; 133(Supplement 1):S17; Abstract 102. Poster \#102.

\section{Author details}

'Department of Dermatology, Faculty of Medicine, University of Chile and Probity Medical Research, Santiago, Chile. ${ }^{2}$ Clinical Research and Probity Medical Research, Waterloo, ON, Canada. ${ }^{3}$ Department of Dermatology, Eastern Virginia Medical School and Virginia Clinical Research Inc., Norfolk, VA, USA. ${ }^{4}$ Department of Dermatology, University of Texas Medical School, Houston, TX, USA. ${ }^{5}$ Pfizer Inc, Groton, CT, USA. ' Quintiles, Cambridge, MA, USA. ${ }^{7}$ Pfizer Inc, New York, NY, USA. ${ }^{8}$ Present address: Statistical Consulting \& Solutions, LLC, Brookline, MA, USA. ${ }^{9}$ Specialty Care Medicines Development Group, Pfizer Inc, 219 E 42nd Street, 7th Floor Room 50, NYO 219/07/01, New York, NY 10017, USA.

Received: 19 December 2014 Accepted: 20 April 2015

Published online: 08 May 2015

\section{References}

1. Parisi R, Symmons DP, Griffiths CE, Ashcroft DM. Global epidemiology of psoriasis: a systematic review of incidence and prevalence. J Invest Dermatol. 2013;133:377-85.

2. Griffiths CE, laccarino L, Naldi L, Olivieri I, Pipitone N, Salvarini C, et al. Psoriasis and psoriatic arthritis: immunological aspects and therapeutic guidelines. Clin Exp Rheumatol. 2014;24(1 Suppl 40):S72-8.

3. Boy MG, Wang C, Wilkinson BE, Chow VF, Clucas AT, Krueger JG, et al. Double-blind, placebo-controlled, dose-escalation study to evaluate the pharmacologic effect of CP-690,550 in patients with psoriasis. J Invest Dermatol. 2009;129:2299-302.

4. Papp KA, Menter A, Strober B, Langley RG, Buonanno M, Wolk R, et al. Efficacy and safety of tofacitinib, an oral Janus kinase inhibitor, in the treatment of psoriasis: a Phase $2 \mathrm{~b}$ randomized placebo-controlled dose-ranging study. Br J Dermatol. 2012;167:668-77.

5. Bissonnette R, Iversen L, Sofen H, Griffiths CE, Foley P, Romiti R, et al. Tofacitinib withdrawal and re-treatment in moderate-to-severe chronic plaque psoriasis: a randomised controlled trial. Br J Dermatol. 2014. Epub ahead of print.

6. Bachelez H, van de Kerkof PCM, Strohal R, Kubanov A, Valenzuela F, Lee JH, et al. Comparison of tofacitinib versus etanercept or placebo in moderate-tosevere chronic plaque psoriasis: a Phase 3 randomized trial [abstract]. Presented at the American Academy of Dermatology - 72nd Annual Meeting. 2014.

7. Ghoreschi K, Laurence A, O'Shea JJ. Janus kinases in immune cell signaling. Immunol Rev. 2009:228:273-87.

8. Li DQ, Chen Z, Song XJ, Luo L, Pflugfelder SC. Stimulation of matrix metalloproteinases by hyperosmolarity via a JNK pathway in human corneal epithelial cells. Invest Ophthalmol Vis Sci. 2004;45:4302-11. 
9. Pepys MB, Hirschfield GM. C-reactive protein: a critical update. J Clin Invest. 2003;111:1805-12.

10. O'Shea JJ. Targeting the Jak/STAT pathway for immunosuppression. Ann Rheum Dis. 2004;63 Suppl 2:ii67-71.

11. Ghoreschi K, Jesson MI, Li X, Lee JL, Ghosh S, Alsup JW, et al. Modulation of innate and adaptive immune responses by tofacitinib (CP-690,550). J Immunol. 2011;186:4234-43.

12. Miquel FJ, Colomina J, Marii Jl, Ortega C. Cytomegalovirus infection in a patient treated with efalizumab for psoriasis. Arch Dermatol. 2009;145:961-2.

13. Petersen B, Lorentzen $\mathrm{H}$. Cytomegalovirus complicating biological immunosuppressive therapy in two patients with psoriasis receiving treatment with etanercept or efalizumab. Acta Derm Venereol. 2008;88:523-4

14. Kikuchi K, Miyazaki Y, Tanaka A, Shigematu H, Kojima M, Sakashita H, et al. Methotrexate-related Epstein-Barr virus (EBV)-associated lymphoproliferative disorder-so-called "Hodgkin-like lesion"-of the oral cavity in a patient with rheumatoid arthritis. Head Neck Pathol. 2010:4:305-11.

15. Mahé E, Descamps V, Grossin M, Fraitag S, Crickx B. CD30+ T-cell lymphoma in a patient with psoriasis treated with ciclosporin and infliximab. Br J Dermatol. 2003;149:170-3.

16. Oh MJ, Lee HJ. A study of hepatitis B virus reactivation associated with rituximab therapy in real-world clinical practice: a single-center experience. Clin Mol Hepatol. 2013;19:51-9.

17. Erard V, Guthrie KA, Varley C, Heugel J, Wald A, Flowers ME, et al. One-year acyclovir prophylaxis for preventing varicella-zoster virus disease after hematopoietic cell transplantation: no evidence of rebound varicella-zoster virus disease after drug discontinuation. Blood. 2007;110:3071-7.

18. NHS. Cytomegalovirus (CMV) - Symptoms [http://www.nhs.uk/Conditions/ Cytomegalovirus/Pages/Symptoms.aspx].

19. Talamonti M, Spallone G, Di Stefani A, Costanzo A, Chimenti S. Efalizumab. Expert Opin Drug Saf. 2011;10:239-51.

20. Shouval D, Shibolet O. Immunosuppression and HBV reactivation. Semin Liver Dis. 2013;33:167-77.

21. Nathan DM, Angus PW, Gibson PR. Hepatitis B and C virus infections and anti-tumor necrosis factor-alpha therapy: guidelines for clinical approach. J Gastroenterol Hepatol. 2006;21:1366-71.

22. Tan X, Balkrishnan R, Feldman SR. Infections associated with the use of tumor necrosis factor-a inhibitors in psoriasis. J Drugs Dermatol. 2013;12:e41-5.

23. Ortigosa LC, Silva LC, Duarte AJ, Takahashi MD, Benard G. Infliximab does not lead to reduction in the interferon-gamma and lymphoproliferative responses of patients with moderate to severe psoriasis. Acta Derm Venereol. 2014;94:26-31.

24. Burmester GR, Mease P, Dijkmans BA, Gordon K, Lovell D, Panaccione R, et al. Adalimumab safety and mortality rates from global clinical trials of six immune-mediated inflammatory diseases. Ann Rheum Dis. 2009;68:1863-9.

25. Pfizer Inc. Xeljanz prescribing information [http://labeling.pfizer.com/ ShowLabeling.aspx?id=959].

26. Mocroft A, Furrer HJ, Miro JM, Reiss P, Mussini C, Kirk O, et al. The incidence of AIDS-defining illnesses at a current CD4 count $\geq 200$ cells/muL in the post-combination antiretroviral therapy era. Clin Infect Dis. 2013;57:1038-47.

27. Izadi M, Jonaidi-Jafari N, Saburi A, Eyni H, Rezaiemanesh MR, Ranjbar R. Prevalence, molecular characteristics and risk factors for cryptosporidiosis among Iranian immunocompromised patients. Microbiol Immunol. 2012;56:836-42

28. Fedele R, Martino M, Garreffa C, Messina G, Console G, Princi D, et al. The impact of early $\mathrm{CD} 4+$ lymphocyte recovery on the outcome of patients who undergo allogeneic bone marrow or peripheral blood stem cell transplantation. Blood Transfus. 2012;10:174-80.

29. Pearson TA, Mensah GA, Alexander RW, Anderson JL, Cannon III RO, Criqui $M$, et al. Markers of inflammation and cardiovascular disease: application to clinical and public health practice: A statement for healthcare professionals from the Centers for Disease Control and Prevention and the American Heart Association. Circulation. 2003;107:499-511.

30. Weitz M, Kiessling C, Friedrich M, Prösch S, Höflich C, Kern F, et al. Persistent CMV infection correlates with disease activity and dominates the phenotype of peripheral CD8+ T cells in psoriasis. Exp Dermatol. 2011;20:561-7.

31. Marcenaro E, Carlomagno S, Pesce S, Della Chiesa M, Parolini S, Moretta A, et al. NK cells and their receptors during viral infections. Immunotherapy. 2011:3:1075-86
32. Moseman EA, lannacone M, Bosurgi L, Tonti E, Chevrier N, Tumanov A, et al. B cell maintenance of subcapsular sinus macrophages protects against a fatal viral infection independent of adaptive immunity. Immunity. 2012:36:415-26.

33. Zinkernagel RM, Hengartner $\mathrm{H}$. Protective 'immunity' by pre-existent neutralizing antibody titers and preactivated T cells but not by so-called 'immunological memory'. Immunol Rev. 2006;211:310-9.

34. Erice A, Tierney C, Hirsch M, Caliendo AM, Weinberg A, Kendall MA, et al. Cytomegalovirus (CMV) and human immunodeficiency virus (HIV) burden, CMV end-organ disease, and survival in subjects with advanced HIV infection (AIDS Clinical Trials Group Protocol 360). Clin Infect Dis. 2003;37:567-78.

35. Lautenschlager I, Loginov R, Mäkisalo H, Hockerstedt K. Prospective study on CMV-reactivations under preemptive strategy in CMV-seropositive adult liver transplant recipients. J Clin Virol. 2013;57:50-3.

36. Levitsky J, Freifeld AG, Puumala S, Bargenquast K, Hardiman P, Gebhart C, et al. Cytomegalovirus viremia in solid organ transplantation: does the initial viral load correlate with risk factors and outcomes? Clin Transplant. 2008;:22:222-8

37. Comar M, Delbue S, Lepore L, Martelossi S, Radillo O, Ronfani L, et al. Latent viral infections in young patients with inflammatory diseases treated with biological agents: prevalence of JC virus genotype 2. J Med Virol. 2013:85:716-22

38. McKeown E, Pope JE, Leaf S. Epstein-Barr virus (EBV) prevalence and the risk of reactivation in patients with inflammatory arthritis using anti-TNF agents and in those who are biologic naive. Open Rheumatol J. 2009;3:30-4.

39. Neimann AL, Hodinka RL, Joshi YB, Elkan M, Van Voorhees AS, Gelfand JM Epstein-Barr virus and human herpesvirus type 6 infection in patients with psoriasis. Eur J Dermatol. 2006;16:548-52.

40. Kim SY, Solomon DH. Tumor necrosis factor blockade and the risk of viral infection. Nat Rev Rheumatol. 2010;6:165-74.

\section{Submit your next manuscript to BioMed Central and take full advantage of:}

- Convenient online submission

- Thorough peer review

- No space constraints or color figure charges

- Immediate publication on acceptance

- Inclusion in PubMed, CAS, Scopus and Google Scholar

- Research which is freely available for redistribution 